\title{
PENERAPAN PEMBELAJARAN MENGGUNAKAN MEDIA PEMBELAJARAN BERBASIS ANIMASI FLASH PADA MATA PELAJARAN PENGUKURAN LISTRIK DI SMKN 5 PADANG
}

\author{
Doni Tri Putra Yanto ${ }^{1}$, Aswardi ${ }^{2}$, Habibullah ${ }^{2}$ \\ Program Studi Pendidikan Teknik Elektro \\ FT Universitas Negeri Padang \\ Email: donitriputra@ft.unp.ac.id
}

\begin{abstract}
This reseach is oriented because there many students leraning result that still not reach the KKM yet at Electricity Measurement subject grade $\mathrm{X}$ TITL in SMKN 5 Padang. There are many factor wich influence the low of students learning result such as learning process by using coventional method and media that used by teacher in learning are module and only use the whiteboard. Based on the factors, then conducted the research in experiment form to increase students learning result by using learning media base flash animation. The method that use in this research is quasy exmeriment with Pretest-Posttest One Group Design. Subject of this research are students grade X L2 SMKN 5 Padang, at semester JulyDecember 2013, wich consist of 31 students. Data collecting in the research use test (Pretest-Posttest) namely objective questions. The questions of test that used presedely conducted the try out to know validity, reliability, level of difficulity, and distinguis power questions. Based on the result of research, obtained 25 items of test questions. The result of research indicated that there is an increasing of students learning result grade X TITL in SMKN 5 Padang at Electricity Measurement subject. Increasing occurs at high level $(0,71)$ where 18 students are on high level and 13 others are on middle level increasing. Based on the result of research, can be concluded that the implementation of flash animation media at Electricity Measurement subject grade X TITL in SMKN 5 Padang can increase students learning result at high level $(0,71)$.

Key words: Flash Animation Media, Learning result
\end{abstract}

\footnotetext{
${ }^{1}$ Mahasiswa Prodi Pendidikan Teknik Elektro untuk wisuda periode September 2014

${ }^{2}$ Dosen Jurusan Teknik Elektro FT-UNP
} 



\section{A. PENDAHULUAN}

Pendidikan adalah suatu hal yang sangat penting dalam suatu negara, kemajuan suatu negara akan tercermin salah satunya dari kualitas pendidikan yang ada pada suatu negara tersebut. Berkualitas atau tidaknya pendidikan itu tergantung pada sistem pendidikan yang diterapkan. Apabila sistem pendidikan yang diterapkan sudah baik maka pendidikan yang dihasilkanpun juga akan semakin berkualitas, namun jika sebaliknya sistem pendidikan yang diterapkan belum baik dan tidak dirumuskan secara matang maka kualitas pendidikan juga akan menurun.

Sistem pendidikan nasional di Indonesia telah dirumuskan dan diatur dalam UndangUndang Republik Indonesia nomor 20 Tahun 2003 tentang Sistem Pendidikan Nasional yang terdiri dari 12 bab dan 77 Pasal. Salah satu yang termasuk dalam sistem pendidikan nasional sebagaimana tercantum dalam UU tersebut adalah adanya jalur pendidikan. "Jalur pendidikan adalah wahana yang dilalui peserta didik untuk mengembangkan potensi diri dalam suatu proses pendidikan yang sesuai dengan tujuan pendidikan" (UU RI no. 20 Tahun 2003 apasal 7 Ayat 6). Jalur pendidikan ini dibagi menjadi tiga jalur yang saling berkaitan dan melengkapi satu sama lain, sebagaimana dijelaskan dalam UU RI no. 20 Tahun 2003 Pasal 13 ayat satu yakni "Jalur pendidikan terdiri atas pendidikan formal, nonformal, dan informal yang dapat saling melengkapi dan memperkaya.". Pendidikan formal merupakan jalur pendidikan yang dilaksanakan secara resmi dibawah naungan pemerintah yaitu Kemendiknas Republik Indonesia, adapun jalur pendidikan tersebut secara berurutan yaitu pendidikan dasar, pendidikan menegah pertama, pendidikan menengah atas, dan perguruan tinggi.

SMKN 5 Padang merupakan salah satu jalur pendidikan formal pendidikan menegah kejuruan yang memiliki tujuan yang sama dengan tujuan sekolah menengah kejuruan pada umumnya yakni menghasilkan lulusan yang berkualitas memiliki keahlian khusus sesuai dengan bidang keahliannya, serta siap kerja. Dalam mencapai tujuan yang telah dirumuskan dan direncanakan oleh sekolah tersebut, tentu ada beberapa unsur yang harus dipertimbangkan dan dilakukan. Salah satu dari beberapa unsur tersebut adalah guru, hal ini dikarenakan guru memegang peranan penting dalam proses pembelajaran dan hasil belajar siswa di kelas. Menurut Hamalik (2010 : 9) "guru merupakan faktor utama dalam usaha meningkatkan mutu pendidikan sekolah yang pada gilirannya akan sangat mempengaruhi kemajuan masyarakat yang menjadi suprasistem sekolah yang bersangkutan. Masyarakat yang semakin rasional dan teknologis semakin membutuhkan jasa sekolah dan atau guru yang bermutu."

Hamalik (2010: 10) mengemukakan bahwa profesionalitas seorang guru dalam melaksanakan proses pembelajaran di kelas akan mempengaruhi dan menentukan hasil belajar peserta didik selama belajar di sekolah yang pada akhirnya tentu juga akan mempengaruhi tercapai atau tidaknya tujuan sekolah. Profesionalitas seorang guru dalam melaksanakan proses pembelajaran di kelas, dapat dilihat dari persiapan awal mengajar, metode mengajar yang diterapkan, serta media pembelajaran yang digunakan pada saat proses pembelajaran berlangsung. Media pembelajaran yang dimaksud adalah media yang dapat menunjang motivasi belajar siswa dan menghilangkan rasa bosan siswa pada saat mengikuti proses pembelajaran di kelas. Pada saat sekarang ini pemerintah merencanakan untuk menerapkan media pembelajaran berbasis Information and Communications Technology (ICT) didalam proses pembelajaran, karena dengan pembelajaran tersebut diduga mampu menghadirkan pembelajaran aktif, inovatif, kreatif, efektif, dan menyenangkan (PAIKEM) (Kompas, 2012 :4).

Berdasarkan hasil observasi yang dilakukan terhadap proses pembelajaran di SMKN 5 Padang, khususnya pada mata pelajaran pengukuran listrik, Guru cenderung menggunakan papan tulis sebagai media dalam proses pembelajaran di kelas dan belum menerapkan media berbasis komputer, dengan alasan mudah dalam penyajian dan persiapannya. Pelaksanaan pembelajaran pada 
mata pelajaran pengukuran listrik kelas $X$ di SMKN 5 Padang. Ketika proses pembelajaran dimulai, seorang guru akan mencatat materi yang akan dibahas di papan tulis, kemudian guru akan menjelaskannya, siswa mencatat dan mendengarkan materi yang telah ditulis dan dijelaskan oleh guru tersebut. Pada akhir pertemuan siswa akan diberi pekerjaan rumah (PR), berupa pertanyaaan-pertanyaan menyangkut materi yang telah dibahas.

Mata pelajaran Pengukuran Listrik di SMKN 5 Padang, standar ketuntasan minimal yang ditetapkan adalah 70. Berdasarkan hasil belajar siswa pada mata diklat Pengukuran Listrik kelas X SMKN 5 Padang tahun 20122013 yang didapatkan dari guru mata pelajaran tersebut, maka dapat diketahui bahwa masih banyak hasil belajar siswa yang belum mencapai KKM, untuk masing-masing kelas yang terdiri dari 3 kelas, kelas XL1 57,1\% hasil belajar siswa di bawah KKM, kelas XL2 $60 \%$ hasil belajar siswa dibawah KKM, dan kelas XL3 63,8\% hasil belajar siswa di bawah KKM. Hal ini membuktikan bahwa masih banyak siswa yang belum lulus dalam mata diklat Dasar Pengukuran Listrik tersebut. Sedangkan berdasarkan kurikulum tingkat satuan pendidikan (KTSP) presentase ketercapaian KKM yang baik dalam satu pelajaran adalah $\geq 80 \%$ dari jumlah siswa.

Dengan kenyataan tersebut, maka perlu dicari alternatif lain dengan melakukan inovasi dan pendekatan dalam penggunaan media pembelajaran yang efektif, dan adaptif dengan kemajuan teknologi untuk penyampaian materi kepada siswa pada saat berlangsungnya proses pembelajaran di kelas, sehingga proses pembelajaran dapat berlangsung aktif, inovatif, kreatif, efektif, dan menyenangkan serta hasil belajar siswa juga baik. Salah satu pendekatan yang diduga mampu mewujudkan situasi pembelajaran tersebut adalah pendekatan pembelajaran menggunakan media interaktif berbasis Information and Communications Technology (ICT) salah satunya adalah media pembelajaran berbasis animasi flash. Menurut Ibiz (dalam Arsyad, 2010 : 32) "Animation is the process of recording and playing back a sequence of stills to achieve the illusion of continues motion". Artinya dalam bahasa Indonesia yakni animasi adalah sebuah proses merekam dan memainkan kembali serangkaian gambar statis untuk mendapatkan sebuah ilusi pergerakan. Secara harfiah, animasi adalah menghidupkan, yakni usaha untuk menggerakkan sesuatu yang tidak bisa bergerak sendiri. Dengan demikian media pembelajaran berbasis animasi flash adalah media pembelajaran yang dibuat dengan menggunakan program macromedia flash, berbentuk gabungan materi, simulasi dengan gambar bergerak yang lebih inovatif untuk menyampaiakan materi pelajaran kepada siswa. Dengan menggunakan media pembelajaran berbasis animasi flash ini mampu menjelaskan materi yang bersifat abstrak, seperti dalam mata pelajaran pengukuran listrik yang banyak menjelaskan bagaimana prinsip kerja alat ukur, bentuk fisik, dan cara penggunaanya, hal ini akan mudah dijelaskan dengan menggunakan media pembelajaran animasi flash, karena media animasi flash ini dapat digabungkan dengan gambar bergerak yang dapat menarik perhatian siswa pada saat proses pembelajaran berlangsung. berdasarkan penelitian yang dilakukan oleh Rohani (2011) yang meneliti tentang peningkatan hasil belajar siswa dengan menggunakan media animasi flash pada mata pelajaran rangkaian listrik kelas $\mathrm{X}$ program keahlian listrik di SMKN 2 Surabaya menunjukkan bahwa media animasi flash dapat meningkatkan hasil belajar siswa dengan persentase $93,80 \%$.

Berdasarkan latar belakang masalah, maka rumusan masalah yang diajukan dalam penelitian ini adalah seberapa besar peningkatan hasil belajar siswa setelah penggunaan media pembelajaran berbasis animasi flash dalam proses pembelajaran pada mata pelajaran Pengukuran Listrik kelas X SMKN 5 Padang?. Tujuan penelitian ini adalah mengungkap peningkatan hasil belajar siswa setelah penggunaan media pembelajaran berbasis animasi flash dalam proses pembelajaran pada mata pelajaran Pengukuran Listrik kelas $\mathrm{X}$ bidang keahlian Teknik Instalasi Tenaga Listrik di SMKN 5 Padang.

\section{B. METODE PENELITIAN}

Metode yang digunakan dalam penelitian ini adalah quasi ekperiment (eksperimen semu). Pretest dilakukan sebelum melaksanakan pembelajaran, untuk mengetahui pengetahuan awal siswa. Sementara posttest dilaksanakan setelah proses pembelajaran dengan menerapkan 
penggunaan media berbasis animasi flash sebagai media pembelajaran. Hasil posttest dibandingkan dengan hasil pretest untuk mengetahui peningkatan hasil belajar siswa setelah pembelajaran dengan mengunakan media pembelajaran berbasis animasi flash.

Penelitian ini mengunakan desain One

Group Pretest - Posttest. Sekelompok subjek diberi perlakuan untuk jangka waktu tertentu berupa pembelajaran dengan menggunakan media pembelajaran berbasis animasi flash. Dalam desain ini, pengukuran dilakukan dua kali. Pengukuran pertama dilakukan sebelum perlakuan. Pengukuran kedua dilakukan setelah perlakuan diberikan.

Subjek dalam penelitian ini adalah kelas X L 2 SMK Negeri 5 Padang pada semester ganjil Juli-Desember 2013. Jumlah subjek penelitian adalah sebanyak 31 siswa. Subjek penelitian ditentukan secara random dari tiga kelas jurusan teknik instalasi tenaga listrik di SMKN 5 Padang yang memiliki kemampuan rata-rata yang sama, hal ini dapat dilihat dari nilai rata-rata kelas dari ujian KD 1 Pengukuran listrik yang homogen dimana ratarata kelas XL 1 adalah 70,16, kelas XL 2 adalah 71,70, dan kelas XL 3 73,33.

Instrumen yang digunakan dalam penelitian ini adalah berupa soal-soal test berbentuk objektif. Soal tes dibuat berdasarkan kisi-kisi soal yang mengacu pada silabus dan rencana pelaksanaan pembelajaran mata pelajaran Pengukuran Listrik SMKN 5 Padang. Sebelum soal tes digunakan maka dilakukan uji coba soal untuk mengetahui validitas, reliabilitas, tingkat kesukaran dan daya beda soal tersebut. Uji coba soal dilakukan di kelas X L3 SMK N 5 Padang.

Penafsiran harga validitas dianalisis menggunakan teknik korelasi point biserial. berdasarkan analisis data uji coba terhadap 30 soal Uji coba, terdapat 25 soal valid dan 5 soal yang tidak valid. Penafsiran harga reliabilitas tes berdasarkan perhitungan rumus Kuder Richardson (KR-20) dengan memperlihatkan kriteria reabilitas, maka keseluruhan soal tes dinyatakan reliabel dengan kriteria sangat tinggi. Hasil perhitungan tingkat kesukaran dianalisis menggunakan teroi yang dikemukakan Arikunto. Berdasarkan hasil analisis dari soal uji coba sebanyak 30 soal, terdapat 21 soal dengan kriteria sedang, 8 soal dengan kriteria mudah, 1 soal dengan kriteria sukar. Perhitungan daya beda dianalisis menggunakan rumus yang dikemukakan oleh Arikunto, berdasarkan hasil analisis dari soal uji coba sebanyak 30 soal, didapat 13 soal kategori baik, 13 soal kategori cukup, dan 4 kategori jelek.

Data hasil belajar siswa dianalisis dengan menggunakan statistik deskriptif yaitu menghitung rata-rata skor (mean) dan simpangan baku standar deviasi. Peningkatan hasil belajar siswa dapat diukur dengan memberikan pretest dan posttest. Peningkatan hasil belajar dianalisis menggunakan Gain Score untuk melihat tingkat perolehan skor dari penerapan media pembelajaran berbasisi animasi Flash pada mata pelajaran Pengukuran Listrik.

\section{HASIL PENELITIAN DAN}

\section{PEMBAHASAN}

\section{Deskripsi Data}

Deskripsi data penelitian ini adalah data hasil belajar PL. Kelas X L2 sebagai subjek penelitian yang diajar dengan menggunakan media pembelajaran Animsi Flash, hasil pretest yang diadakan sebelum pembelajaran diperoleh skor tertinggi $=76$ dan skor terendah $=24$ dengan jumlah siswa 31 orang. Dengan perhitungan statistik diperoleh hasil rata-rata skor $\mathrm{X}$ (pretest) adalah $=50,6$, simpangan baku $(\mathrm{s})=$ 14,11. Sebaran data frekuensi dapat dilihat pada tabel distribusi frekuensi dan histogram berikut.

Tabel . distribusi frekuensi pretest

\begin{tabular}{|c|c|c|}
\hline No & Nilai & Frekuensi \\
\hline 1 & $23---31$ & 3 \\
\hline 2 & $32---40$ & 6 \\
\hline 3 & $41---49$ & 4 \\
\hline 4 & $50---58$ & 7 \\
\hline 5 & $59---67$ & 7 \\
\hline 6 & $68---76$ & 4 \\
\hline \multicolumn{2}{|c|}{ Jumlah } & $\mathbf{3 1}$ \\
\hline \multicolumn{2}{|c|}{ Simpangan baku } & $\mathbf{1 4 , 1 1}$ \\
\hline
\end{tabular}

Untuk lebih jelas berikut adalah histogram data hasil pretest. 


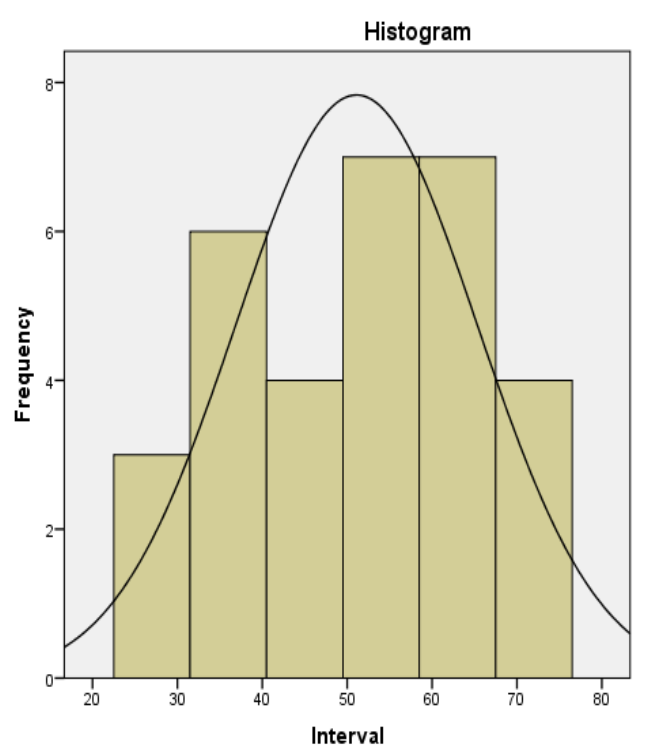

Adapun hasil post-test yang diadakan setelah pembelajaran, skor tertinggi $=96$ dan yang terendah 68 . Untuk rata rata skor adalah $=82,42$. Simpangan baku 6,81. Sebaran data frekuensi dapat dilihat pada Tabel Distribusi Frekuensi berikut.

Tabel . distribusi frekuensi posttest

\begin{tabular}{|c|c|c|}
\hline No & Nilai & Frekuensi \\
\hline 1 & $67---71$ & 1 \\
\hline 2 & $72---76$ & 5 \\
\hline 3 & $77--81$ & 2 \\
\hline 4 & $82---86$ & 6 \\
\hline 5 & $87--91$ & 10 \\
\hline 6 & $92---96$ & 7 \\
\hline \multicolumn{2}{|c|}{ Jumlah } & $\mathbf{3 1}$ \\
\hline \multicolumn{2}{|c|}{ Simpangan baku } & $\mathbf{6 , 8 1}$ \\
\hline
\end{tabular}

Untuk lebih jelas berikut adalah histogram data hasil posttest.

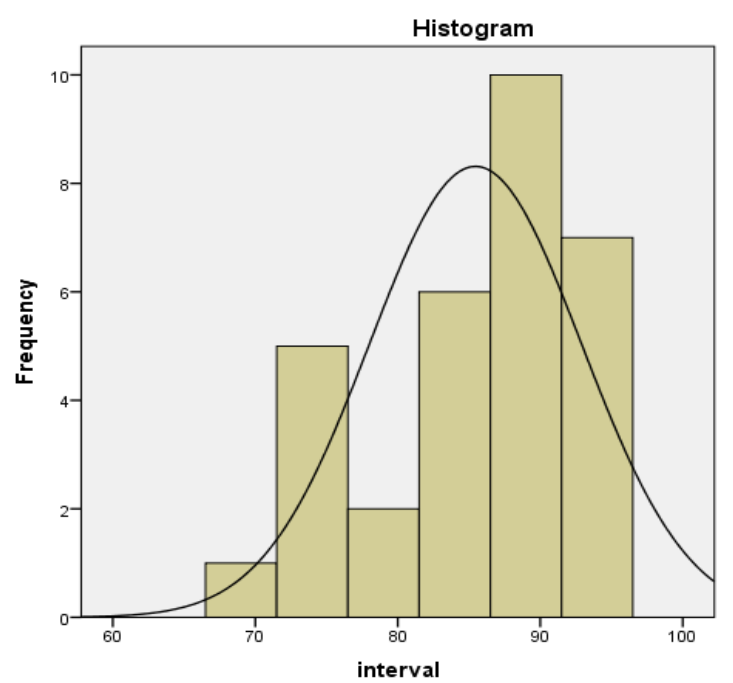

2. Analisis Peningkatan Hasil Belajar

Peningkatan hasil belajar siswa dalam suatu proses pembelajaran dapat diukur dengan memberikan pretest dan posttest. Hake (1999) mengemukakan bahwa Peningkatan hasil belajar dapat dianalisis menggunakan gainscore dengan rumus sebagai berikut:

$$
<g>=\frac{\left(<S_{f}>-<S_{i}>\right)}{\left(100-<S_{i}>\right)}
$$

Dari perhitungan Gain score didapatkan bahwa semua hasil belajar siswa mengalami peningkatan. Rata-rata kenaikan hasil belajar di tentukan menggunakan rumus Gain Score $=0,71$ dengan kriteria perolehan Gain Score pada rentang $\mathrm{NG} \geqq 0,7$ yaitu kategori tinggi. Ini berarti peningkatan hasil belajar siswa termasuk dalam kategori tinggi. Dengan demikian dapat dijelaskan bahwa hasil belajar siswa setelah pembelajaran dengan menggunakan Media Animasi Flash mengalami peningkatan.

\section{Pembahasan}

Berdasarkan hasil penelitian, penerapan Media Animasi Flash dapat membuat siswa lebih aktif dan lebih berpartisipasi dalam dalam proses pembelajaran. Penerapan media animasi flash mempunyai manfaat positif apabila diterapkan di ruang kelas. Pada penelitian ini menggunakan uji Gain Score. 
Pertama dilakukan pre-test untuk melihat kemampuan awal siswa sebelum menerapkan media animasi flash. Dari hasil pretest diperoleh rata-rata hasil belajar siswa sebesar $=50,6$. Kemudian dilakukan uji normalitas dan didapat bahwa data terdistribusi normal. Setelah melihat kemampuan awal maka diberi perlakuan dengan menggunakan media animasi flash selama empat minggu sebanyak empat kali pertemuan kemudian diberi posttest. Dari hasil perhitungan data setelah diberi perlakuan didapatkan rata-rata hasil belajar siswa sebesar 85,42. Kemudian dilakukan uji normalitas dan didapat bahwa data terdistribusi normal. Langkah berikutnya adalah melihat peningkatan hasil belajar siswa dengan menggunakan Gain Score dan didapat bahwa hasil belajar siswa mengalami peningkatan dengan kategori tinggi.

Dari penjelasan di atas, Penerapan media animasi flash dapat meningkatkan hasil belajar siswa, karena adanya peningkatan hasil belajar yang signifikan antara pretest dan posttest. Hasil penelitian ini diperkuat oleh penelitian yang dilakukan Parana (2010) dalam penelitiannya yang berjudul "Peningkatan Hasil Belajar Siswa dengan Menggunkan Media Animasi pada Mata Pelajaran Pengetahuan Dasar Teknik Mesin Di Kelas X TP B SMKN 1 Padang". Menunjukkan terdapat peningkatan hasil belajar siswa melalui pembelajaran dengan menggunakan media animasi sebagai media pembelajaran. Kemudian dianalisis menggunakan rumus Gainscore didapatkan peningkatan hasil belajar siswa setelah pembelajaran menggunakan media animasi, berada pada taraf sedang $(\langle g\rangle=0,64)$.

Berdasarkan penelitian yang dilakukan terdapat beberapa kendala dalam menerapkan media animasi flash ini, seperti: ada beberapa siswa yang tidak hadir, peralatan mendukung media yang belum lengkap yaitu belum tersedianya layar proyektor di kelas maka proyektor harus di arahkan ke papan tulis sehingga mengurangi nilai estetika media yang telah disiapkan.

\section{KESIMPULAN DAN SARAN}

\section{Kesimpulan}

Berdasarkan analisis data dan pembahasan yang telah dilakukan pada penelitian ini, maka dapat disimpulkan bahwa:

a. Hasil belajar siswa dalam mata pelajaran Pengukuran Listrik kelas X dengan menggunakan media animasi flash sebagai media pembelajaran dalam proses pembelajaran di kelas didapatkan nilai rata-rata dari 31 orang siswa yaitu 85,42.

b. Hasil belajar siswa setelah dilaksanakan proses pembelajaran dengan menggunakan media animasi flash sebagai media pembelajaran (nilai posttest) lebih baik jika dibandingkan dengan nilai sebelumnya (nilai pretest).

c. Peningkatan hasil belajar siswa yang terjadi termasuk pada kategori tinggi yaitu 0,71 , dengan demikian dapat dijelaskan bahwa hasil belajar siswa pada mata diklat Pengukuran Listrik setelah proses pembelajaran dilakukan dengan menggunakan media animasi flash sebagai media pembelajaran mengalami peningkatan.

\section{Saran}

Berdasarkan hasil penelitian yang telah diperoleh setelah diadakannya penelitian pada mata diklat Pengukuran Listrik kelas X TITL SMKN 5 Padang, maka saran yang dapat diberikan adalah sebagai berikut:

a. Kepala sekolah dan Waka bidang kurikulum agar mengadakan pelatihan penerapan media pembelajaran yang berbasis ICT dalam proses pembelajaran bagi guruguru di sekolah terutama guru produktif

b. Guru mata pelajaran pengukuran llistrik dapat menggunakan media animasi flash dalam pelaksanaan proses pembelajaran di kelas sebagai salah satu media alternatif untuk meningkatkan hasil belajar akhir siswa. 
c. Guru mata pelajaran pengukuran listrik agar lebih memperbanyak menggunakan media berbasis komputer saat proses pembelajaran berlangsung, sesusai dengan program pemerintah untuk meningkatkan motivasi dan hasil belajar siswa. Karena selain dapat mempermudah guru menyampaikan materi juga dapat membantu siswa dalam memahami materi pelajaran yang akan diajarakan ketika proses pembelajaran berlangsung.

d. Supaya penelitian yang sama dilakukan pada materi pembelajaran yang lain dan dengan jumlah sampel yang lebih besar. Agar nampak lebih jelas gambaran bahwa apakah media animasi flash ini dapat digunakan pada semua mata diklat dan mampu meningkatkan hasil akhir belajar siswa setelah mengikuti proses pembelajaran.

Catatan: Artikel ini disusun berdasarkan skripsi penulis dengan Pembimbing I Drs. H. Aswardi, M.T. dan Pembimbing II Habibullah, S.Pd, M.T.

\section{DAFTAR PUSTAKA}

Arikunto, Suharsimi. (2007). Dasar-Dasar Evaluasi Pendidikan. Jakarta : Bumi Aksara.

Arikunto, Suharsmi. (2006). Prosedur Penelitian Suatu Pendekatan Praktik. Jakarta: Rineka Cipta.

Arsyad, Azhar. (2010). Media Pembelajaran. Jakarta: Raja Wali Press.

Djaafar. (2001). Evaluasi Belajar. Bandung : Bumi Aksara.

Fadhil, M. (2011). “ Perbedaan Hasil Belajar Siswa yang Diajar Menggunakan Media PresentasiAnimasi Flash dengan yang Diajar Dengan Media Konvensional Pada Kelas XI IPA SMAN 8 Padang”. Skripsi tidak diterbitkan. FMIPA-UNP
Hake, R. R. (1999). "Analizing change/Gain Score, American Educational, Reseach Associations Divisions Measurement and Research methodology". www. List_asu.edu.com (diakses tanggal 2 Agustus 2013)

Hamalik, Oemar. (2010). Perencanaan Pembelajaran Berdasarkan Pendekatan Sistem. Jakarta : Bumi Aksara.

Parana, Agung. (2010). "Peningkatan Hasil Belajar Siswa dengan Menggunakan Media Animasi pada Mata Pelajaran Pengetahuan Dasar Teknik mesin di Kelas X TP B SMKN 1 Padang". Skripsi tidak diterbitkan. FT-UNP

Purwanto. (2004). Belajar dan Pembelajaran. Jakarta : Depdikbud.

Purwanto, Ngalim. (2004). Prinsip-Prinsip Dan Teknik Evaluasi Pengajaran. Jakarta : Rosda Karya.

Rohani. (2010). "Penggunaan Media Berbasis Animasi Tipe Macroflash dalam Upaya Meningkatkan Hasil Belajar siswa Kelas X TPTL SMKN 2 Surabaya". Skripsi tidak diterbitkan. Teknik-UNESA.

Sagala. (2004). Konsep-konsep Pembelajaran Jakarta : Kencana Prenada Media Group.

Sanjaya. (2009). Metode Pembelajaran. Bandung : Alfa Beta Bandung

Sardiman, Arief. (2007). Interaksi dan Motivasi mengajar. Jakarta : Grafindo.

Sardiman, Arief dkk. (2005). Media Pembelajaran (Pengertian Pengembangan Pemanfaatan). Jakarta : Raja Wali Press.

Sudjana, Nana. (2002). Penelitian dan Penelitian Pendidikan. Bandung: Sinar Bandung Algesindo.

Sugiyanta, I Gede. (2005). "Pemanfaatan Media Teknologi Dalam Pembelajaran". Laporan Penelitian. UNIB. 
Zakir, Ibnu . (2011). “Pembelajaran berbasis ICT ((Information And Comunication Technology)". $\quad$ www.berbagiilmu.blogspot.com (diakses pada tanggal 21 Juni 2013)

(2011). "Wajah Pendidikan Indonesia". Kompas. (6 Agustus 2011). Hlm. 6 